\title{
BMJ Open Experiences of long-term life-limiting conditions among patients and carers: what can we learn from a meta-review of systematic reviews of qualitative studies of chronic heart failure, chronic obstructive pulmonary disease and chronic kidney disease?
}

Carl R May, ${ }^{1,2,3}$ Amanda Cummings, ${ }^{1,2}$ Michelle Myall, ${ }^{1,2}$ Jonathan Harvey, ${ }^{1,2}$ Catherine Pope, ${ }^{1,2}$ Peter Griffiths, ${ }^{1,2}$ Paul Roderick, ${ }^{2,3,4}$ Mick Arber, ${ }^{5}$ Kasey Boehmer, ${ }^{6}$ Frances S Mair, ${ }^{7}$ Alison Richardson ${ }^{1,2,3}$

To cite: May CR,

Cummings A, Myall $\mathrm{M}$, et al. Experiences of long-term lifelimiting conditions among patients and carers: what can we learn from a meta-review of systematic reviews of qualitative studies of chronic heart failure, chronic obstructive pulmonary disease and chronic kidney disease?. BMJ Open 2016;6: e011694. doi:10.1136/ bmjopen-2016-011694

- Prepublication history and additional material is available. To view please visit the journal (http://dx.doi.org/ 10.1136/bmjopen-2016011694).

Received 26 February 2016 Revised 24 August 2016 Accepted 26 August 2016

CrossMark

For numbered affiliations see end of article.

Correspondence to Professor Carl R May; c.r.may@soton.ac.uk

\section{ABSTRACT}

Objectives: To summarise and synthesise published qualitative studies to characterise factors that shape patient and caregiver experiences of chronic heart failure (CHF), chronic obstructive pulmonary disease (COPD) and chronic kidney disease (CKD).

Design: Meta-review of qualitative systematic reviews and metasyntheses. Papers analysed using content analysis.

Data sources: CINAHL, EMBASE, MEDLINE, PsychINFO, Scopus and Web of Science were searched from January 2000 to April 2015.

Eligibility criteria for selecting studies:

Systematic reviews and qualitative metasyntheses where the participants were patients, caregivers and which described experiences of care for CHF, COPD and CKD in primary and secondary care who were aged $\geq 18$ years

Results: Searches identified 5420 articles, 53 of which met inclusion criteria. Reviews showed that patients' and caregivers' help seeking and decisionmaking were shaped by their degree of structural advantage (socioeconomic status, spatial location, health service quality); their degree of interactional advantage (cognitive advantage, affective state and interaction quality) and their degree of structural resilience (adaptation to adversity, competence in managing care and caregiver response to demands).

Conclusions: To the best of our knowledge, this is the first synthesis of qualitative systematic reviews in the field. An important outcome of this overview is an emphasis on what patients and caregivers value and on attributes of healthcare systems, relationships and practices that affect the distressing effects and consequences of pathophysiological deterioration in CHF, COPD and CKD. Interventions that seek to empower individual patients may have limited
Strengths and limitations of this study

- This is the first synthesis of qualitative systematic reviews focusing on patient and carer experience of life-limiting chronic conditions that consider them against pathophysiological deterioration towards the terminal phase of illness.

- The review builds on systematic review and analysis to develop a robust conceptual model of the factors that shape patient and caregiver expectations and choices about help seeking and self-care, and which shows how these are the products of rational decisions and experiential processes.

- The review demonstrates the value of qualitative research that identifies and characterises important aspects of patient experience and health and healthcare-related behaviours.

- The review provides proposed domains of patient and caregiver experience that may represent potential targets for new interventions to support patients and caregivers to improve capacity and better manage workload to promote improved experience of illness.

- This is an overview of a heterogeneous set of papers and as such there was considerable variability in research aims, methods and perspectives which is a limitation of the study.

effectiveness for those who are most affected by the combined weight of structural, relational and practical disadvantage identified in this overview. We identify potential targets for interventions that could address these disadvantages.

Systematic review registration number: PROSPERO CRD42014014547. 


\section{INTRODUCTION}

Globally, health services are responding to an increasingly older population characterised by complexes of multimorbidity that include long-term life-limiting conditions. ${ }^{1}$ As the burden of disease grows, so too does another kind of problem-burden of treatment ${ }^{2}$ - which occurs as the work of disease management has been shifted from formal healthcare provision to selfmanagement at home. This shift has been a major focus of policy effort in health services that deliver care for people with long-term conditions. ${ }^{3}{ }^{4}$ However, for a significant proportion of people with chronic and often life-limiting conditions, illness trajectories are characterised by major disruptions. ${ }^{5}{ }^{6}$ They include increasingly frequent cycles of hospital admission and discharge, supported self-management at home and readmission as exacerbation events occur. ${ }^{7}$ Here, there is a complex balancing act to be performed around the work of being a patient. This involves managing the limiting effects of symptoms while also managing complex therapeutic regimens, self-monitoring technologies and assessment regimes, and interactions with healthcare providers and organisations. ${ }^{8-10}$ These admissiondischarge-readmission cycles may lead to increasing experiences of complex workload for patients and their carers which can sometimes be overwhelming and may have important effects of quality of life..$^{11-13}$

Understanding the parameters of patient workload and the experiences of complexity that stem from it has recently become an important focus of research on longterm conditions, ${ }^{14-20}$ and has led to modelling work that has focused on the relationships between treatment burden, symptom burden and healthcare systems. ${ }^{12} 13$ 21-23 This has taken place against the background of a programme of policy and practice development that, internationally, focuses on reworking the sick-role and rethinking the relationship between the sick person and healthcare system, ${ }^{24}$ and understanding the dynamic role of social networks in supporting them. ${ }^{25}$ Yet problems remain in the way that researchers, clinicians and policymakers understand patients with long-term conditions. In policy terms, this group is sometimes seen as the source of inappropriate and excess demand on primary care services and emergency departments. ${ }^{26}$ These factors are becoming increasingly important as healthcare systems find themselves under significant pressure to control costs and reduce spending.

Much clinical and health services research on longterm conditions focuses on controlling symptoms or delaying their onset-achieving equilibrium, even when this may be punctuated by acute exacerbation eventsbut in this paper, we are concerned with the experiences of people with chronic heart failure (CHF), chronic obstructive pulmonary disease (COPD) and chronic kidney disease (CKD) as they approach the terminal phase of their illness. Here, factors leading to pathophysiological deterioration limit their capacity to participate independently in self-management and healthcare processes. ${ }^{27}$ As this happens, they experience new dependencies on health services and new demands on informal networks that provide care and social support. All of these factors must be balanced against the wider demands of everyday life, ${ }^{23}$ and we need to better understand how these problems are framed and experienced by people with long-term conditions, and this review aims to identify, characterise and explain the common factors that shape patient journeys through care in CHF, COPD and CKD' ${ }^{28}$ in order to inform future intervention development.

\section{METHODS AND ANALYSIS \\ Eligibility criteria}

This is a systematic review including data from qualitative reviews and the eligibility criteria for study inclusion have been developed using the PICO (participants, interventions, comparators and outcomes) framework (box 1).

\section{Inclusion and exclusion criteria}

We included papers that met the PICO criteria (box 1) and were published in English reporting qualitative reviews of patients' or caregivers' experiences of healthcare provision. Some of these studies also included the views of health professionals. Mixed methods reviews were included if analysis of primary qualitative studies could be clearly differentiated from analysis of other kinds of primary studies in the text. Papers were excluded if they were: reports of treatment; reports of healthcare organisation or delivery which were not concerned with patients' or caregivers' experience; summaries or discussions of the literature or editorials, notes, letters and case reports.

\section{Searches and information sources}

Searches were conducted in the following bibliographic databases: MEDLINE(R) In-Process and Other

\section{Box 1 PICO criteria for including studies}

Population: Patients (aged >18 years and diagnosed with chronic heart failure, chronic kidney disease or chronic obstructive pulmonary disease), and formal or informal caregivers and health professionals in healthcare settings (including triage services, emergency departments, in-patient hospital care, outpatient/ambulatory care departments, primary care service/family practice doctor's offices, community nursing services or at home).

- Intervention: Experiences of healthcare provision.

- Comparator: This review not limited to comparator studies. Where comparators are present these may include: usual care or control groups.

- Outcomes: Qualitative data on patients and caregivers experiences of care for those with chronic heart failure, chronic obstructive pulmonary disease or chronic kidney disease.

- Study type: Secondary studies (qualitative or mixed method systematic reviews, qualitative meta-syntheses and metaethnographies). 
Non-Indexed Citations and MEDLINE(R); Embase; CINAHL Plus; Science Citation Index Expanded; Social Sciences Citation Index; Arts and Humanities Citation Index; PsycINFO; and Scopus. Searches were completed by April 2015 and identified papers published between 1 January 2000 and 31 December 2014. Full details of the search strategy are provided in figure 1.

\section{Study selection and data extraction}

All titles and abstracts were screened independently by $\mathrm{AC}$ and CRM or AC and MM. Screening of full-text articles was undertaken independently by AC and CRM with assistance from JH. Disagreements about eligibility for inclusion at title and abstract screening stage were resolved by discussion and majority vote; disagreements about inclusion at full-paper screening were resolved by discussion, or by referral $(n=3)$ to colleagues not involved in this review.

\section{Quality assessment}

Although there are now several quality assurance frameworks for assessing primary qualitative studies,${ }^{29-31}$ there are none that are generally accepted for meta-reviews of such studies. Quality appraisal of included papers was conducted retrospectively at the request of the journal, and was undertaken using a tool that combined elements of the AMSTAR ${ }^{32}$ and CASP $^{33}{ }^{34}$ instruments. The tool is shown in online supplementary appendix 1. Each paper was appraised independently by two researchers. Overall scores were expressed as a percentage. Papers scoring over $80 \%$ were awarded a high $(\mathrm{H})$ quality rating, those between $60 \%$ and $80 \%$ a medium (M) rating and papers scoring below $60 \%$ were attributed a low (L) rating. No papers were excluded on grounds of quality, and agreement statistics were not calculated. Results of this exercise (presented in tables 1-3) should be treated with considerable caution because this meta-review includes studies using integrative (mixed methods) reviews, thematic analyses and qualitative metasyntheses applied in very different ways by their authors.

\section{Data analysis and synthesis}

Formal data for analysis consisted of the discussion and conclusions sections of each included paper, and a qualitative content analysis ${ }^{35} 36$ of attributions within these was undertaken. An attribution is a statement that characterises a state and that relies on a causal inference or explanation about the supposed antecedents of that state. ${ }^{37}$ Attributions were identified on (1) patient and caregivers' experiences of illness and journeys through care, (2) experiences of healthcare practices and (3) evaluations of illness and healthcare practices. Each identified attribution was matched to any causal inferences and explanations for it that were made by authors. Where such attributions were unexplained, and where explanations could not be directly linked to an attribution about patient or caregiver experience, they were

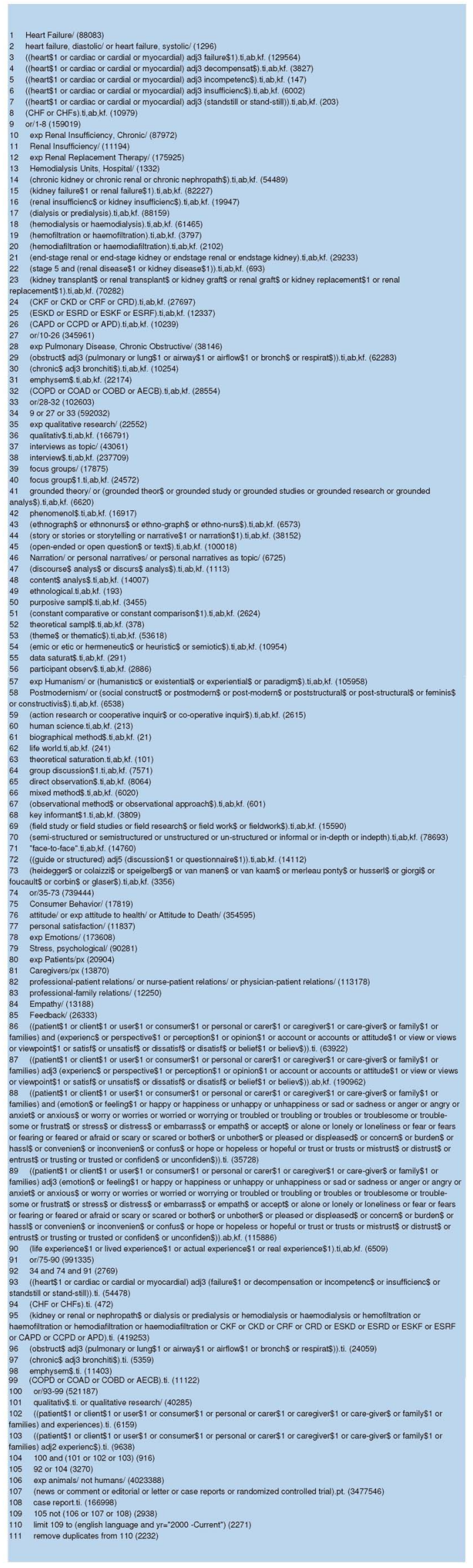

Figure 1 Search strategy. 


\begin{tabular}{|c|c|c|c|c|c|c|}
\hline Review & Year & Type of review & Phenomena of interest & $\begin{array}{l}\text { Number of } \\
\text { qualitative } \\
\text { studies included }\end{array}$ & Key $\operatorname{aim}(\mathbf{s})$ & $\begin{array}{l}\text { Quality } \\
\text { score }\end{array}$ \\
\hline $\begin{array}{l}\text { Molloy et a }{ }^{38} \\
\text { (UK) }\end{array}$ & 2005 & $\begin{array}{l}\text { Mixed methods (integrative) } \\
\text { review }\end{array}$ & Role of family caregivers & $3 / 16$ & $\begin{array}{l}\text { Evaluate effect of CHF on caregivers' well-being; } \\
\text { evaluate role of caregivers in management of } \\
\text { CHF; outline policy and practice implications of } \\
\text { current studies }\end{array}$ & $\begin{array}{l}77 \% \\
M\end{array}$ \\
\hline $\mathrm{Yu}^{39}$ & 2007 & $\begin{array}{l}\text { Qualitative systematic review } \\
\text { with thematic analysis of } \\
\text { qualitative studies }\end{array}$ & Older people's experiences & 14 & $\begin{array}{l}\text { Synthesising qualitative studies of people with } \\
\text { CHF to advance understanding of lived experience } \\
\text { and inform intervention and service development }\end{array}$ & $\begin{array}{l}94 \% \\
\mathrm{H}\end{array}$ \\
\hline $\begin{array}{l}\text { McEntee et a }{ }^{40} \\
\text { (USA) }\end{array}$ & 2009 & $\begin{array}{l}\text { Mixed methods (integrative) } \\
\text { review }\end{array}$ & Barriers to $\mathrm{CHF}$ care & 15 & $\begin{array}{l}\text { To synthesise research on barriers to CHF care at } \\
\text { patient, provider and system levels }\end{array}$ & $\begin{array}{l}61 \% \\
M\end{array}$ \\
\hline $\begin{array}{l}\text { Westland et } a f^{11} \\
\text { (UK) }\end{array}$ & 2009 & $\begin{array}{l}\text { Qualitative integrative review } \\
\text { of living with heart failure }\end{array}$ & $\begin{array}{l}\text { Experiences and } \\
\text { perceptions of people living } \\
\text { with CHF }\end{array}$ & 18 & $\begin{array}{l}\text { To explore the experiences and perceptions of } \\
\text { patients who have heart failure }\end{array}$ & $\begin{array}{l}\mathrm{M} \\
77 \%\end{array}$ \\
\hline $\begin{array}{l}\text { Hopp et } a f^{42} \\
\text { (USA) }\end{array}$ & 2010 & $\begin{array}{l}\text { Systematic review with } \\
\text { thematic analysis of } \\
\text { qualitative studies }\end{array}$ & Older people's experiences & 15 & $\begin{array}{l}\text { Understand the 'lived experience' of CHF among } \\
\text { older people to inform social work practice with } \\
\text { this group }\end{array}$ & $\begin{array}{l}72 \% \\
M\end{array}$ \\
\hline $\begin{array}{l}\text { Jeon et } a{ }^{43} \\
\text { (Australia) }\end{array}$ & 2010 & Narrative review & $\begin{array}{l}\text { Experience of living with } \\
\text { CHF }\end{array}$ & 30 & $\begin{array}{l}\text { Conduct a narrative review of qualitative studies } \\
\text { of people's experiences of living with CHF to } \\
\text { develop a wide-ranging understanding of the } \\
\text { patient experience of CHF }\end{array}$ & $\begin{array}{l}\mathrm{M} \\
77 \%\end{array}$ \\
\hline $\begin{array}{l}\text { Barclay et } a^{44} \\
\text { (UK) }\end{array}$ & 2011 & $\begin{array}{l}\text { Systematic review with } \\
\text { narrative synthesis of } \\
\text { qualitative studies }\end{array}$ & End-of-life care in $\mathrm{CHF}$ & $17 / 23$ & $\begin{array}{l}\text { Identify patient and professional preferences } \\
\text { around end-of-life conversations in } \mathrm{CHF} \text {, and to } \\
\text { identify barriers and facilitators of these } \\
\text { conversations }\end{array}$ & $\begin{array}{l}77 \% \\
M\end{array}$ \\
\hline $\begin{array}{l}\text { Dev et al }{ }^{45} \\
\text { (USA) }\end{array}$ & 2011 & Qualitative metasynthesis & $\begin{array}{l}\text { Self-care CHF with } \\
\text { comorbid conditions }\end{array}$ & 3 & $\begin{array}{l}\text { Identify and characterise factors that affect } \\
\text { integration of CHF self-care with other comorbid } \\
\text { conditions }\end{array}$ & $\begin{array}{l}38 \% \\
L\end{array}$ \\
\hline $\begin{array}{l}\text { Dickson et } a{ }^{46} \\
\text { (USA) }\end{array}$ & 2011 & $\begin{array}{l}\text { Systematic review with } \\
\text { thematic analysis of } \\
\text { qualitative studies }\end{array}$ & $\begin{array}{l}\text { Self-care in CHF with } \\
\text { comorbidities }\end{array}$ & 3 & $\begin{array}{l}\text { Identify and characterise aspects of self-care for } \\
\mathrm{CHF} \text { that are complicated by comorbidities }\end{array}$ & $\begin{array}{l}55 \% \\
\mathrm{~L}\end{array}$ \\
\hline $\begin{array}{l}\text { Kang et } a f^{47} \\
\text { (China) }\end{array}$ & 2011 & Qualitative metasynthesis & Role of family caregivers & 10 & $\begin{array}{l}\text { Synthesise qualitative studies of caregivers' } \\
\text { experiences of CHF to inform nurses as they } \\
\text { support families affected by CHF }\end{array}$ & $\begin{array}{l}94 \% \\
\mathrm{H}\end{array}$ \\
\hline Low et $a f^{48}(\mathrm{UK})$ & 2011 & $\begin{array}{l}\text { Systematic review with } \\
\text { thematic analysis of } \\
\text { qualitative studies }\end{array}$ & End-of-life care & $28 / 48$ & $\begin{array}{l}\text { Explore studies on patient and professional } \\
\text { understandings of disease processes and } \\
\text { perceived needs and experiences of care } \\
\text { provision in palliative care for CHF }\end{array}$ & $\begin{array}{l}77 \% \\
M\end{array}$ \\
\hline $\begin{array}{l}\text { Tierney et al }{ }^{49} \\
\text { (UK) }\end{array}$ & 2011 & $\begin{array}{l}\text { Qualitative systematic review } \\
\text { with framework analysis }\end{array}$ & Physical activity & 20 & $\begin{array}{l}\text { Identify barriers and facilitators of physical activity } \\
\text { in CHF and identify beliefs and behaviours that } \\
\text { could be targeted by interventions to promote } \\
\text { activity }\end{array}$ & $\begin{array}{l}88 \% \\
\mathrm{H}\end{array}$ \\
\hline $\begin{array}{l}\text { Thomas and } \\
\text { Clark } \\
\text { (Canada) }\end{array}$ & 2011 & Qualitative metasynthesis & Sex and gender & $5 / 6$ & $\begin{array}{l}\text { Identify and understand sex-related and } \\
\text { gender-related factors that shape women's } \\
\text { self-care beliefs and behaviours in CHF }\end{array}$ & $\begin{array}{l}83 \% \\
\mathrm{H}\end{array}$ \\
\hline
\end{tabular}


Table 1 Continued

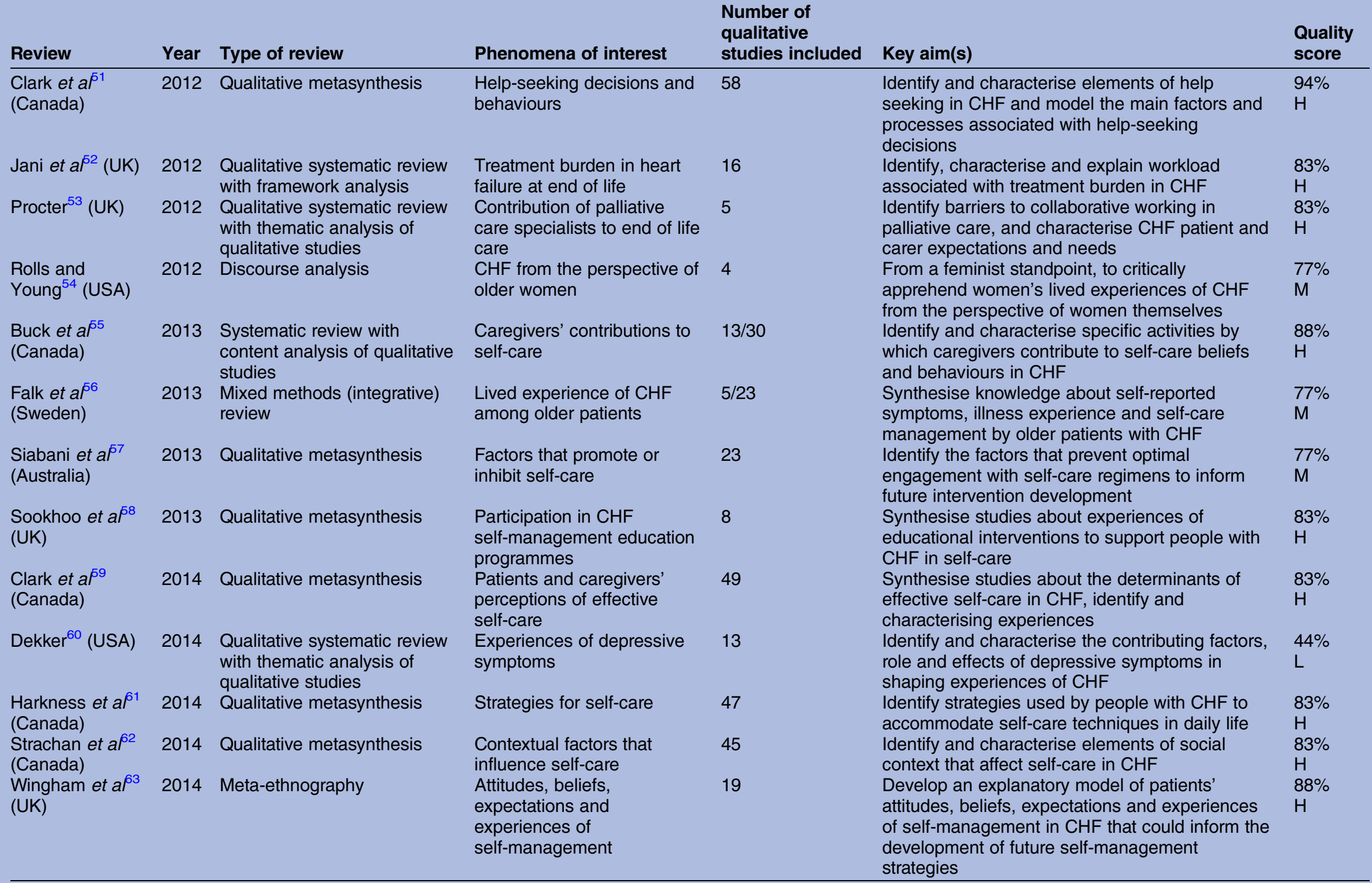

CHF, chronic heart failure. 
Table 2 Summary of overview of qualitative systematic reviews and metasyntheses of experiences of COPD

\begin{tabular}{|c|c|c|c|c|c|c|}
\hline Review & Year & Type of review & Phenomena of interest & $\begin{array}{l}\text { Number of } \\
\text { qualitative } \\
\text { studies included }\end{array}$ & Key $\operatorname{aim}(\mathbf{s})$ & $\begin{array}{l}\text { Quality } \\
\text { score }\end{array}$ \\
\hline $\begin{array}{l}\text { Gysels et } a f^{64} \\
\text { (UK) }\end{array}$ & 2007 & $\begin{array}{l}\text { Qualitative systematic review } \\
\text { with thematic analysis of } \\
\text { qualitative studies }\end{array}$ & $\begin{array}{l}\text { Experiences of } \\
\text { breathlessness }\end{array}$ & 22 & $\begin{array}{l}\text { Synthesise qualitative evidence about breathlessness } \\
\text { as a common symptom of multiple conditions, including } \\
\text { COPD (and CHF) }\end{array}$ & $\begin{array}{l}83 \% \\
\mathrm{H}\end{array}$ \\
\hline $\begin{array}{l}\text { Cullen and } \\
\text { Stiffler }^{65} \text { (USA) }\end{array}$ & 2009 & Qualitative metasynthesis & $\begin{array}{l}\text { Experiences of oxygen } \\
\text { therapy }\end{array}$ & 4 & $\begin{array}{l}\text { Identify and characterise new evidence about patients' } \\
\text { perspectives on oxygen therapy in COPD and other } \\
\text { conditions to guide intervention development }\end{array}$ & $\begin{array}{l}83 \% \\
\mathrm{H}\end{array}$ \\
\hline $\begin{array}{l}\text { Disler et } a^{66} \\
\text { (Australia) }\end{array}$ & 2011 & $\begin{array}{l}\text { Mixed methods (integrative) } \\
\text { review }\end{array}$ & $\begin{array}{l}\text { Factors that promote or } \\
\text { inhibit self-care }\end{array}$ & $13 / 44$ & $\begin{array}{l}\text { Identify and characterise factors that influence self-care } \\
\text { in COPD }\end{array}$ & $\begin{array}{l}88 \% \\
\mathrm{H}\end{array}$ \\
\hline $\begin{array}{l}\text { Keating et } a \rho^{7} \\
\text { (Australia) }\end{array}$ & 2011 & $\begin{array}{l}\text { Mixed methods (integrative) } \\
\text { review }\end{array}$ & $\begin{array}{l}\text { Barriers to participation in } \\
\text { rehabilitation }\end{array}$ & $5 / 11$ & $\begin{array}{l}\text { Identify and characterise factors that affect attendance } \\
\text { and participation in pulmonary rehabilitation for COPD }\end{array}$ & $\begin{array}{l}88 \% \\
\mathrm{H}\end{array}$ \\
\hline $\begin{array}{l}\text { Kirkpatrick } \\
\text { et } a f^{8} \text { (UK) }\end{array}$ & 2012 & Qualitative metasynthesis & $\begin{array}{l}\text { Patients and caregivers' } \\
\text { perceptions of support }\end{array}$ & 39 & $\begin{array}{l}\text { Identify and characterise forms and experiences of } \\
\text { support for people with COPD from informal and formal } \\
\text { caregivers, and identify and characterise those forms of } \\
\text { support believed to be beneficial }\end{array}$ & $\begin{array}{l}77 \% \\
M\end{array}$ \\
\hline $\begin{array}{l}\text { Giacomini } \\
\text { et a }{ }^{69} \\
\text { (Canada) }\end{array}$ & 2012 & Qualitative metasynthesis & $\begin{array}{l}\text { Experiences of living and } \\
\text { dying with COPD }\end{array}$ & 101 & $\begin{array}{l}\text { Synthesise studies of people with COPD and their } \\
\text { informal caregivers, identify and characterise insights } \\
\text { into their experiences and inform future interventions }\end{array}$ & $\begin{array}{l}88 \% \\
H\end{array}$ \\
\hline $\begin{array}{l}\text { Thorpe et } a l^{70} \\
\text { (Australia) }\end{array}$ & 2012 & $\begin{array}{l}\text { Mixed methods (integrative) } \\
\text { review }\end{array}$ & $\begin{array}{l}\text { Participation in physical } \\
\text { activity }\end{array}$ & $8 / 11$ & $\begin{array}{l}\text { Identify and characterise barriers and enablers of } \\
\text { participation in physical activity, including pulmonary } \\
\text { rehabilitation, among people with COPD }\end{array}$ & $\begin{array}{l}94 \% \\
\mathrm{H}\end{array}$ \\
\hline $\begin{array}{l}\text { Langer et } a l^{71} \\
(\mathrm{UK})\end{array}$ & 2012 & Qualitative metasynthesis & $\begin{array}{l}\text { Use of unscheduled/ } \\
\text { emergency care in } \\
\text { long-term conditions }\end{array}$ & $5 / 42$ & $\begin{array}{l}\text { Identify and characterise the range of psychosocial and } \\
\text { other influences on use of unscheduled care by people } \\
\text { with long-term conditions, including COPD and CHF }\end{array}$ & $\begin{array}{l}83 \% \\
\mathrm{H}\end{array}$ \\
\hline $\begin{array}{l}\text { Momen et al } \\
\text { UK }\end{array}$ & 2012 & $\begin{array}{l}\text { Qualitative systematic literature } \\
\text { review and narrative synthesis }\end{array}$ & End-of-life conversations & $12 / 30$ & $\begin{array}{l}\text { Identify factors that promote or inhibit discussions of } \\
\text { management of end of life in COPD }\end{array}$ & $\begin{array}{l}66 \% \\
M\end{array}$ \\
\hline $\begin{array}{l}\text { De Souza Pinto } \\
\text { et } a l^{73} \text { (Spain) }\end{array}$ & 2013 & Meta-ethnography & $\begin{array}{l}\text { Impact of pulmonary } \\
\text { rehabilitation }\end{array}$ & 8 & $\begin{array}{l}\text { Explore the lived experience of COPD and identifying } \\
\text { positive and negative aspects of pulmonary } \\
\text { rehabilitation from the perspective of people with COPD }\end{array}$ & $\begin{array}{l}94 \% \\
\mathrm{H}\end{array}$ \\
\hline $\begin{array}{l}\text { Harrison et } a l^{74} \\
\text { (UK) }\end{array}$ & 2013 & Qualitative metasynthesis & $\begin{array}{l}\text { Impact of acute } \\
\text { exacerbation events in } \\
\text { COPD }\end{array}$ & 8 & $\begin{array}{l}\text { Identify and characterise people's experiences of } \\
\text { exacerbation events that inhibit engagement with } \\
\text { pulmonary rehabilitation in COPD }\end{array}$ & $\begin{array}{l}100 \% \\
H\end{array}$ \\
\hline $\begin{array}{l}\text { Disler et } a l^{75} \\
\text { (Australia) }\end{array}$ & 2014 & Qualitative metasynthesis & $\begin{array}{l}\text { Lived experience of } \\
\text { COPD }\end{array}$ & 22 & $\begin{array}{l}\text { Identify and characterise the lived experience of COPD } \\
\text { and inform the development of healthcare services }\end{array}$ & $\begin{array}{l}83 \% \\
\mathrm{H}\end{array}$ \\
\hline $\begin{array}{l}\text { Oishi et } a l^{76} \\
\text { (UK) }\end{array}$ & 2014 & $\begin{array}{l}\text { Mixed methods (integrative) } \\
\text { review }\end{array}$ & $\begin{array}{l}\text { Provision of palliative care } \\
\text { for patients with } \\
\text { non-cancer }\end{array}$ & $17 / 30$ & $\begin{array}{l}\text { Identify and characterise aspects of professional role, } \\
\text { performance and barriers and facilitators to primary } \\
\text { palliative care }\end{array}$ & $\begin{array}{l}77 \% \\
M\end{array}$ \\
\hline
\end{tabular}

CHF, chronic heart failure; COPD, chronic obstructive pulmonary disease. 
Table 3 Summary of overview of qualitative systematic reviews and metasyntheses of experiences of CKD

\begin{tabular}{|c|c|c|c|c|c|c|}
\hline Review & Year & Type of review & Phenomena of interest & $\begin{array}{l}\text { Number of } \\
\text { qualitative } \\
\text { studies included }\end{array}$ & Key $\operatorname{aim}(\mathbf{s})$ & $\begin{array}{l}\text { Quality } \\
\text { score }\end{array}$ \\
\hline Low et $a l^{77}$ (UK) & 2008 & $\begin{array}{l}\text { Mixed methods } \\
\text { (integrative) review }\end{array}$ & $\begin{array}{l}\text { Impact of end-stage CKD on } \\
\text { caregivers }\end{array}$ & $11 / 36$ & $\begin{array}{l}\text { Identify all studies exploring the impact of CKD on } \\
\text { 'close persons' during and after withdrawal from } \\
\text { dialysis, and during end-of-life care }\end{array}$ & $\begin{array}{l}77 \% \\
M\end{array}$ \\
\hline $\begin{array}{l}\text { Morton et } a l^{78} \\
\text { (Australia) }\end{array}$ & 2010 & $\begin{array}{l}\text { Qualitative systematic } \\
\text { review with thematic } \\
\text { analysis of studies }\end{array}$ & $\begin{array}{l}\text { Views of people and carers } \\
\text { on treatment } \\
\text { decision-making in CKD }\end{array}$ & 18 & $\begin{array}{l}\text { Identify patient and carer perspectives on treatment } \\
\text { decisions, and characterise factors that shape these } \\
\text { decisions }\end{array}$ & $\begin{array}{l}77 \% \\
M\end{array}$ \\
\hline $\begin{array}{l}\text { Wadd et } a l^{79} \\
\text { (Australia) }\end{array}$ & 2011 & $\begin{array}{l}\text { Qualitative systematic } \\
\text { review with thematic } \\
\text { analysis of studies }\end{array}$ & $\begin{array}{l}\text { Parents' experiences of } \\
\text { dialysis for CKD }\end{array}$ & 17 & $\begin{array}{l}\text { Identify and characterise experiences of parenting } \\
\text { while undergoing dialysis for CKD, to inform } \\
\text { family-centred holistic care }\end{array}$ & $\begin{array}{l}72 \% \\
M\end{array}$ \\
\hline $\begin{array}{l}\text { Bayhakki and } \\
\text { Hattakit }^{80} \\
\text { (Indonesia) }\end{array}$ & 2012 & $\begin{array}{l}\text { Qualitative } \\
\text { metasynthesis }\end{array}$ & $\begin{array}{l}\text { Experience of } \\
\text { haemodialysis for CKD }\end{array}$ & 10 & $\begin{array}{l}\text { Characterise and understand aspects of lived } \\
\text { experience of haemodialysis }\end{array}$ & $\begin{array}{l}83 \% \\
\mathrm{H}\end{array}$ \\
\hline $\begin{array}{l}\text { Harwood and } \\
\text { Clark }^{81} \\
\text { (Canada) }\end{array}$ & 2012 & $\begin{array}{l}\text { Qualitative } \\
\text { metasynthesis }\end{array}$ & $\begin{array}{l}\text { Decision-making about } \\
\text { treatment modalities in CKD }\end{array}$ & 16 & $\begin{array}{l}\text { Understand how people with CKD decide on } \\
\text { treatment modalities and to explain underuse of } \\
\text { home dialysis }\end{array}$ & $\begin{array}{l}83 \% \\
\mathrm{H}\end{array}$ \\
\hline $\begin{array}{l}\text { Makaroff } \\
\text { (Canada) }\end{array}$ & 2012 & $\begin{array}{l}\text { Qualitative } \\
\text { metasynthesis }\end{array}$ & $\begin{array}{l}\text { Lived experience of } \\
\text { end-stage CKD }\end{array}$ & 13 & $\begin{array}{l}\text { Understand experiences of people with end-stage } \\
\text { CKD aiming to inform future interventions }\end{array}$ & $\begin{array}{l}77 \% \\
M\end{array}$ \\
\hline $\begin{array}{l}\text { Moustakas } \\
\text { et } a f^{\beta 3} \text { (Australia) }\end{array}$ & 2012 & $\begin{array}{l}\text { Mixed methods } \\
\text { (integrative) review }\end{array}$ & $\begin{array}{l}\text { Supportive care needs of } \\
\text { older people with advanced } \\
\text { CKD }\end{array}$ & $4 / 12$ & $\begin{array}{l}\text { Identify and characterise supportive care needs of } \\
\text { older people with advanced CKD, to inform future } \\
\text { research and intervention design }\end{array}$ & $\begin{array}{l}66 \% \\
M\end{array}$ \\
\hline $\begin{array}{l}\text { Tong et } a^{\beta 4} \\
\text { (Australia) }\end{array}$ & 2013 & $\begin{array}{l}\text { Qualitative systematic } \\
\text { review with thematic } \\
\text { analysis of studies }\end{array}$ & $\begin{array}{l}\text { Perspectives of adults living } \\
\text { with peritoneal dialysis }\end{array}$ & 39 & $\begin{array}{l}\text { Identify and characterise experiences, attitudes and } \\
\text { beliefs relating to peritoneal dialysis }\end{array}$ & $\begin{array}{l}83 \% \\
\mathrm{H}\end{array}$ \\
\hline $\begin{array}{l}\text { Casey et } a^{85} \\
\text { (Australia) }\end{array}$ & 2014 & $\begin{array}{l}\text { Qualitative systematic } \\
\text { review with thematic } \\
\text { analysis of studies }\end{array}$ & $\begin{array}{l}\text { Perspectives on } \\
\text { haemodialysis vascular } \\
\text { access }\end{array}$ & 46 & $\begin{array}{l}\text { Identify and characterise the psychosocial impact of } \\
\text { vascular access for haemodialysis, and the } \\
\text { concerns, beliefs and attitudes of patients during } \\
\text { treatment. Informing strategies to maximise quality of } \\
\text { life and quality of care }\end{array}$ & $\begin{array}{l}88 \% \\
\mathrm{H}\end{array}$ \\
\hline $\begin{array}{l}\text { Luckett et } a^{\beta 6} \\
\text { (Australia) }\end{array}$ & 2014 & $\begin{array}{l}\text { Mixed methods } \\
\text { (integrative) review }\end{array}$ & $\begin{array}{l}\text { Advance care planning for } \\
\text { adults }\end{array}$ & $6 / 54$ & $\begin{array}{l}\text { Identification of advance care planning interventions } \\
\text { and evaluations and inform understanding of barriers } \\
\text { and facilitators to implementation }\end{array}$ & $\begin{array}{l}100 \% \\
H\end{array}$ \\
\hline $\begin{array}{l}\text { Palmer et } a{ }^{\beta 7} \\
\text { (New Zealand) }\end{array}$ & 2014 & $\begin{array}{l}\text { Qualitative systematic } \\
\text { review with thematic } \\
\text { analysis of studies }\end{array}$ & $\begin{array}{l}\text { Patients view of dietary and } \\
\text { fluid restrictions in CKD }\end{array}$ & 46 & $\begin{array}{l}\text { How people with CKD meet the challenge of } \\
\text { managing complex fluid and dietary requirements, to } \\
\text { inform clinical practice }\end{array}$ & $\begin{array}{l}83 \% \\
\mathrm{H}\end{array}$ \\
\hline $\begin{array}{l}\text { Tong et } a^{\beta 8} \\
\text { (Australia) }\end{array}$ & 2014 & $\begin{array}{l}\text { Qualitative systematic } \\
\text { review with thematic } \\
\text { analysis of studies }\end{array}$ & $\begin{array}{l}\text { Women's experiences of } \\
\text { pregnancy and CKD }\end{array}$ & 15 & $\begin{array}{l}\text { Identify and characterise factors that affect how } \\
\text { women with CKD experience pregnancy, to inform } \\
\text { shared decision-making processes and to optimise } \\
\text { quality of care and quality of life }\end{array}$ & $\begin{array}{l}83 \% \\
\mathrm{H}\end{array}$ \\
\hline
\end{tabular}




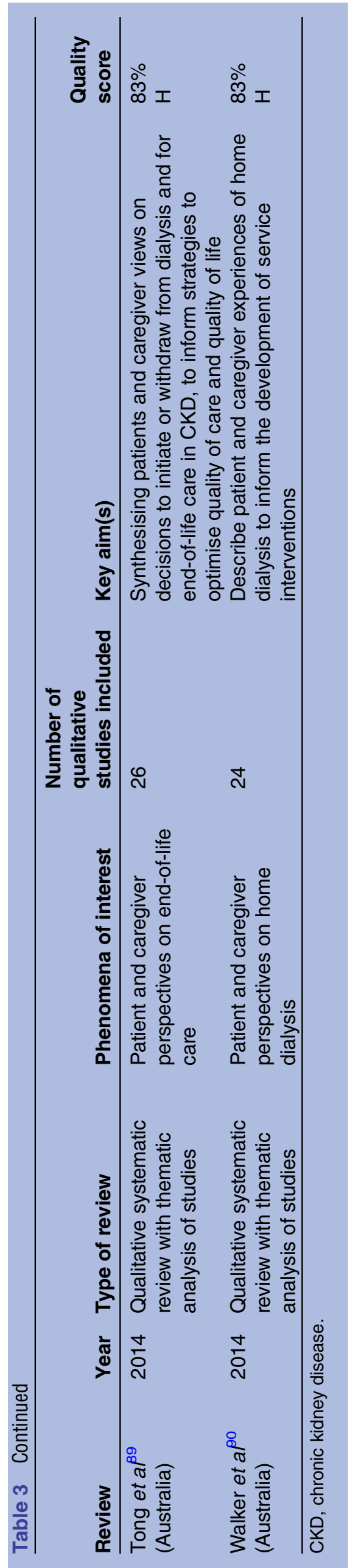

traced back through the analysis presented in the results section of each review or metasynthesis. This tracing work was especially important where integrative reviews were concerned since these drew on quantitative and qualitative primary studies and we wished to exclude the former from our analysis. Related attributions and explanations were grouped together in sets and then simple explanatory propositions were formulated to characterise them. Formal analysis of textual data was undertaken by CRM and then reviewed in detail by other authors.

\section{RESULTS}

\section{Results of searches}

The review process is shown in figure 2: 10866 possible articles were identified, and after the removal of duplicates, 5420 were left. Of these, 847 were reviews or metasyntheses. Further screening identified 132 potentially eligible papers and full-paper reading led to 53 reviews that fully met the criteria for inclusion. These reviews consisted of 26 articles concerned with $\mathrm{CHF}^{38-63}$ (see table 1); 13 articles concerned with $\mathrm{COPD}^{64-76}$ (see table 2) and 14 studies of $\mathrm{CKD}^{77-90}$ (see table 3). Of these, most reviews focused on aspects of everyday experiences of long-term conditions with an emphasis on understanding patient and caregiver behaviours related to self-management regimens, and a subset of 10 papers explored elements of experiences of care towards end of life. ${ }^{44} 48 \quad 5253697677828689$ These 53 reviews synthesised the results of 559 reports of primary qualitative studies.

Three types of review method are represented in this sample of papers: integrative reviews that synthesised qualitative studies alongside other studies (often cross-sectional surveys, reviews of routinely collected clinical data and case notes); 38405666677076778386 systematic reviews of qualitative studies that employed some kind of thematic analysis; ${ }^{39} 41-4446484952535560647278798485878890$ and reviews that were identified by their authors as qualitative meta-syntheses or meta-ethnographies. ${ }^{45} 47505157-5961-63$ 65686971 73-75 80-82 89 In addition, one paper was explicitly characterised as a discourse analysis by its authors. ${ }^{54}$ Irrespective of the method that authors stated that they had employed, the body of reviews and metasyntheses included in this synthesis were largely descriptive in their approach to data analysis.

\section{Social structure}

Socioeconomic disadvantages that play a role in structuring the unequal distribution of health problems and inequalities in access to health services were often treated as 'contextual' factors, ${ }^{49} 6270717376$ and reviews emphasised the importance of social inequalities, employing broad and inclusive definitions of disadvantage that include access to transport and other socioeconomic resources, and environmental factors such as poor air quality and exposure to other sources of environmental pollution. Other structural variables, such as 
Figure 2 PRISMA flow chart.

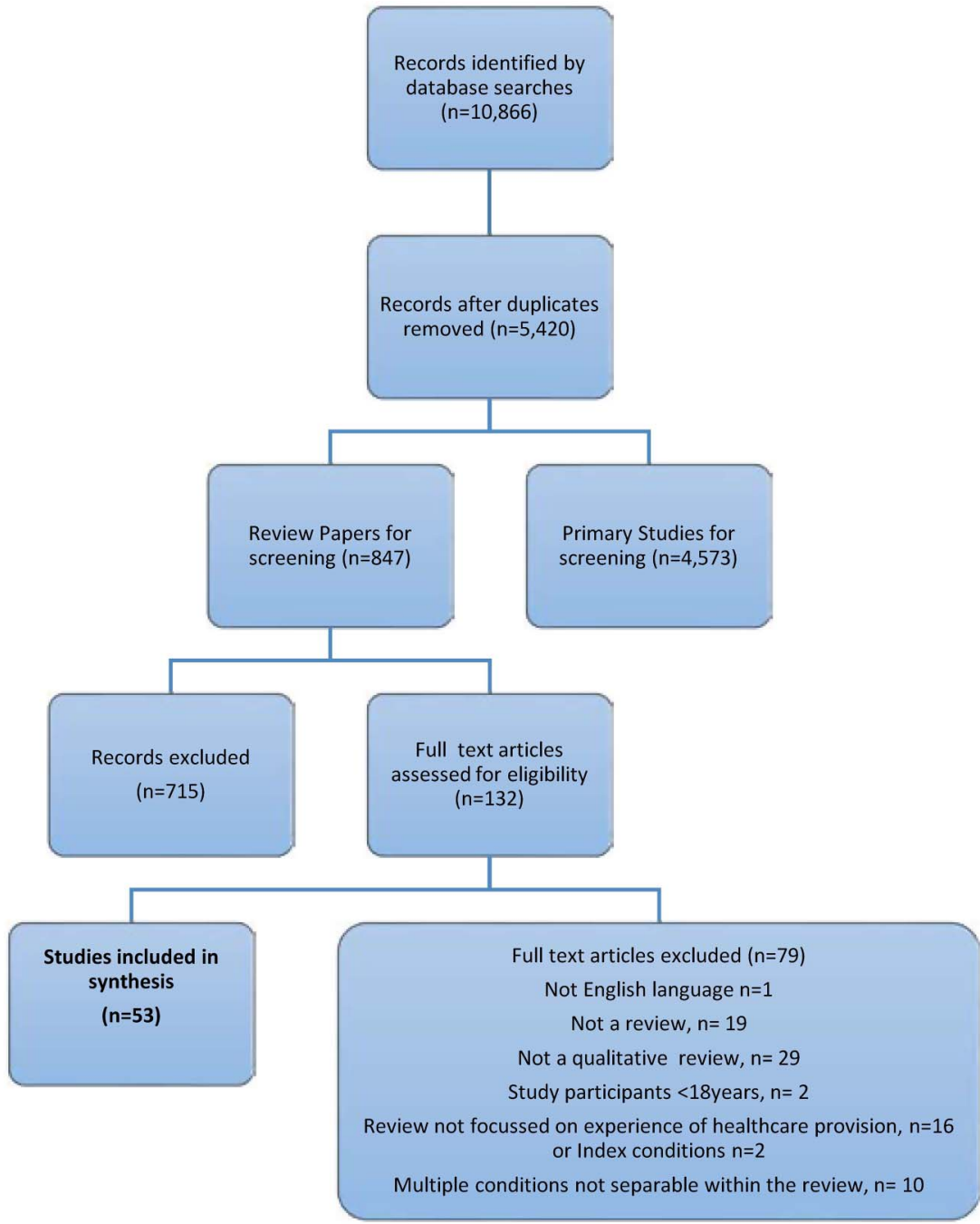

gender and ethnicity, were not well represented at all. $^{42} 50 \quad 54 \quad 88$ One demographic variable that was given consideration was age: many reviews explicitly dealt with CHF, COPD and, to a lesser extent, CKD as diseases of old age. The views of patients and caregivers were often that such diseases were a 'natural' consequence of ageing.

\section{System behaviour}

Experiences of poorly coordinated and organised care, $^{43} \quad 45 \quad 48 \quad 52$ poor communications between professionals $^{40} \quad 45 \quad 47 \quad 48 \quad 52$ and between patients and professionals $^{42} 47$ were common. Even so, patients and caregivers had high expectations of clinicians, especially when they needed urgent assistance, ${ }^{76}$ even though clinicians were sometimes seen as lacking important expertise around coordinating care in multimorbidities. ${ }^{46}$ Treatment decisions were restricted not only by the quality and timing of information but also by dealing with the prospect of death. ${ }^{78} 81$ Conversations about treatment decisions were often focused on day-to-day problems of disease management, ${ }^{445378} 83$ and seemed to be rarely oriented towards decisions about the future -especially about palliative and supportive care, and discontinuation of treatment (eg, implantable cardiac devices or dialysis). ${ }^{45} 81-8386$ Reviews suggested that conversations about end-of-life issues rarely took place, either because of patients' poor understanding of their conditions or because professionals recognise high levels of prognostic uncertainty and the risk of sudden death. When patients were aware of disease progression and potential prognosis, they were able to discuss end-of-life issues openly, ${ }^{53}$ although the key decision-maker was the clinician. $^{44} 48$ This may mean that the life-limiting nature of disease was not apparent to patients. ${ }^{41} 75$ When it was, some patients saw living wills, and advance care plans as useful decision-making tools, ${ }^{77}$ even though these could lead to conflict and discomfort. ${ }^{59}$ Experiences of poor communications seemed to be endemic in the patient groups included in all of the reviews included in this synthesis, and common to all healthcare systems.

\section{Understanding disease progression and symptoms}

Reviews emphasised the importance of patients' and caregivers' poor understanding of disease, disease progression and the significance of symptoms. $^{40} \quad 41 \quad 43 \quad 45 \quad 50 \quad 52 \quad 58 \quad 59 \quad 69 \quad 75 \quad 76 \quad 88$ Women and older people were presented as being particularly 
vulnerable to a lack of correct knowledge; $;^{39} 5054$ and most patients were seen as ill-prepared to face their disease ${ }^{45}$ and symptoms. ${ }^{88}$ Symptom recognition was particularly challenging, in the context of comorbidity, for patients, caregivers and clinicians. ${ }^{43} 4557$ Poor understanding of disease mechanisms and progression was characterised as a key source of distress for patients and caregivers. ${ }^{64}$ It was sometimes attributed to low levels of health literacy ${ }^{56}$ and to fragmented, limited and ineffective educational resources. ${ }^{57} 83$ It led to negative consequences that included failure to understand the life-limiting nature of disease; wrong beliefs about the causes of acute exacerbations of symptoms; incorrect assumptions and actions that follow from these; $;^{41} 466469$ feelings of powerlessness over disease progression ${ }^{74}$ and low expectations of clinical interventions. ${ }^{76}$ These factors were seen to interfere with symptom management and help seeking, ${ }^{6566}$ and adherence to self-management regimens. ${ }^{5761}$ They were especially important where patients needed to understand how comorbidities 'fitted' with each other ${ }^{4670}$ and needed to manage complex polypharmacy. ${ }^{64}$ Unpredictable disease progression made planning daily and longer term activities difficult and either meant that threat to life was not explicitly acknowledged, or that if it was, uncertainty interfered with planning for end of life and the initiation of palliative care. ${ }^{39} 427682$

\section{Self-management regimes}

Self-management regimes include participating in pulmonary and cardiac rehabilitation programmes; adhering to instructions about exercise and diet; adhering to often complex therapeutic regimens; operating and monitoring medical devices (such as implantable cardiac devices, or home oxygen equipment) along with other technologies and assessment regimes. Self-management also includes significant administrative and organisational work, as people with long-term conditions interact with healthcare providers and organisations. $^{8-10}$ Reviews suggested that the performance of self-management tasks was valued by patients, who actively invested in them and displayed considerable resilience as they did so. ${ }^{58} 617384$ They sought to overcome the disruptive effect of illness on their lives and to assimilate self-management strategies into everyday life. ${ }^{63}$ However, negative changes in self-identity, selfesteem, social functioning, physical capacity and experiences of social loss were common. ${ }^{41} 43 \quad 7984$ Fear, anxiety, isolation and discomfort were consistently characterised as consequences of disease ${ }^{49576082}$ that interfered with participation in self-management. ${ }^{77}$ Experienced symptoms and physical limitations led to attempts to avoid physical activities ${ }^{53} 7180$ in case they precipitated (potentially fatal) acute episodes. ${ }^{42} 47577174$ Adherence to self-management programmes was adversely affected by disruption to everyday activities and routines, ${ }^{40} 67$ and by conflicts with competing selfmanagement regimes or treatment regimens for comorbidities. $^{43} 4546555887$
Reviews also offered evidence of adaptive processes in the face of disease progression and the disruptions that stem from this. ${ }^{63}$ Such adaptations included the accumulation of expertise and associated self-management strategies developed over time. ${ }^{43}{ }^{61}$ Patients sought to develop strategies that would ensure better symptom control, and that increased the duration of periods between acute episodes and reduced the impact of acute episodes. ${ }^{67} 87$ Poor quality self-management instruction or interactions with health professionals could have adverse effects, ${ }^{51}$ especially because patients were sensitive to evidence of clinicians' doubts about the value of different self-management strategies. ${ }^{67}$

\section{Burdens for patients and caregivers}

Inequalities of access to informal support and material assistance from family and social network members ${ }^{71}$ and health professionals, ${ }^{40} 70$ and problems of continuity of care, ${ }^{76}$ figured prominently across all three conditions. Experiences of symptom burdens (eg, breathlessness, fatigue and anxiety) were characterised as leading to affective responses. These included psychological responses to limitations on everyday activities and relationships that led to social isolation, loss of hope and fear of death. ${ }^{4350668087}$ Feelings of worthlessness and burdensomeness ${ }^{60} 89$ were commonly experienced. Some reviews suggested that they were experienced more acutely by women. ${ }^{4150} 54$ Against this background, social support was characterised as important, ${ }^{38} 84$ especially when it was connected with practical contributions to self-management that might include symptom monitoring and management, information gathering and interaction with health professionals and help seeking at moments of crisis. ${ }^{55}$ Although social support was often marked by shared experiences of solidarity and collective engagement, patients appreciated the disruptive and demanding effects of their illness on caregivers and their wider social networks. ${ }^{47} 8189$ These included increased workload, and economic consequences-as well as stress, anxiety and isolation-as disease progressed. ${ }^{38} 397790$

Reviews also pointed to the importance of lifesustaining interventions (eg, dialysis and implantable devices) and patient and caregiver preferences for those interventions that promoted self-efficacy and delayed disease progression. ${ }^{45} 73$ They provided opportunities to gain some control and establish a limited degree of normality. ${ }^{8490}$ However, some patients reported heightened vulnerability, feelings of dependence and unpreparedness, along with anxiety about their capacity to perform procedures and the risks of treatment failure or complications. ${ }^{85}{ }^{90}$ Using health technologies of different kinds brought only 'temporary mastery' over disease, and required continuous attention. ${ }^{85}$ This led to a constant tension between managing disease and technological supports, and the other demands of everyday life. ${ }^{58} 6579$ Technologies could be intrusive because of the demands that they made on patient and caregiver time and 
effort. $^{81}$ Assistive technologies could also have the paradoxical effect of leaving patients and caregivers feeling isolated from clinical help and that their homes had been 'medicalised'. ${ }^{90}$ When technological supports were no longer effective or needed to be withdrawn for other reasons, patients and caregivers often felt abandoned. ${ }^{81}$

\section{Hospital admissions}

Patients valued self-management and care at home, but did not always have full confidence in primary or community care services. They also sometimes found selfmanagement limiting, isolating and frightening. ${ }^{70}$ In this context, help seeking was a problem because of difficulties in recognising and interpreting symptoms. ${ }^{51}$ The security of hospital care is therefore an important element of their experience and they may therefore seek it out. ${ }^{67}$ Experience of acute and uncontrollable exacerbations is frightening and distressing, but patients and caregivers often experience service provision that categorises them as anxious when anxiety is a consequence, rather than a cause, of exacerbation episodes. ${ }^{64}$ Here, patients regarded unscheduled and emergency care as one of a number of sensible options among a range of possible destinations for help seeking. ${ }^{73}$ They therefore regard accessing such care as a rational response to acute disease episodes. ${ }^{73}$

\section{DISCUSSION}

\section{Overcoming individual deficits}

Key features of the literature included in this study are assumptions about the presence and importance of two kinds of deficits. First, there is a patient deficit rooted in poor understanding and non-adherence to treatment regimens, and that is expressed through lack of motivation to participate. Second, there is a professional deficit rooted in poor communications and coordination and that is expressed in reluctance to engage in end-of-life planning. An important finding of our synthesis, however, is that these individual behaviours are linked to structural factors (eg, socioeconomic status, spatial location) and system qualities that are much more than mere 'context'. They may act as causal mechanisms that have important determining effects on the experiences of patients and caregivers. Their role, however, is underinvestigated. Against the background of these effects, patients and caregivers value resilience, functional performance and social support that make practical contributions to self-management, and they develop cumulative expertise in negotiating selfmanagement tasks and in navigating healthcare systems. They also carry significant burdens. The burden of symptoms-the inevitable consequences of pathophysiological deterioration-may include frightening and potentially lethal acute episodes of disease. The burden of treatment includes additional moral responsibilities, affective and cognitive demands, increased workload and economic consequences of participation in self- management and formal healthcare. Once again, these factors are underinvestigated but may also include mechanisms that likely shape patient and caregiver behaviours.

The effects of pathophysiological deterioration mean that patients and caregivers experience cognitive, affective and interactional disadvantages derived from prognostic uncertainty. They also experience poor communications among health professionals and uncoordinated services, and they have an increasingly limited capacity to make sense of their illness and its effects. Although self-management practices, technological investments and clinical interventions are valued, they may bring only temporary gains. Their benefits are ultimately overwhelmed by disease progression and do not change its final outcome.

\section{Process tracing model}

An important secondary aim of this synthesis was to identify potential targets for interventions. In table 4 , we identify and characterise a set of constructs that form a framework for the development of coordinated interventions that could act together to relieve the weight of structural, systemic, relational and individual disadvantages that are conferred on patients and caregivers experiencing these diseases and their comorbidities. Reducing these burdens is likely to improve patient outcomes and thus reduce system costs. However, it makes no sense to isolate them from each other. The constructs that are defined in table 4 represent phenomena that already are, or are in principle, measurable. In figure 3, we offer a logic model of the processes that link them: proposing that patient expectations and choices in the face of pathophysiological deterioration are mediated by their personal attributes (eg, socioeconomic status) as well as their experiences of healthcare, and moderated by the extent of resilience that they together with their caregivers and wider social support networks possess which may be influenced by a myriad of circumstantial factors. ${ }^{25}$ We need to better understand the design and implementation of interventions that might mitigate some of the key system and behavioural factors that negatively affect patient and caregiver experiences and outcomes, and that modify the chains of causation that are implicated in them.

\section{Limitations}

Like all evidence syntheses, ours is subject to a number of important limitations. This is an overview of a heterogeneous set of reports. There was considerable variability in research aims, perspectives and methods. There were also very significant differences in authors' underlying assumptions about patient and professional motivation and behaviour. A limitation of syntheses of qualitative work is that these variations in assumptions and perspectives, and methodological heterogeneity, are often difficult to tease out. It is therefore not clear to what extent reviews continuously reproduce a particular set of ideas 


\section{Finding}

1. Structural, spatial and systemic disadvantages are important factors that inhibit active engagement with formal healthcare and self-management

2. Patients and caregivers experience multiple affective, cognitive and interactional disadvantages as they seek to participate in encounters with clinicians, decisions about their formal healthcare and self-management processes

3. Patients and caregivers value resilience, functional performance and social support that make a practical contribution to formal healthcare and self-management

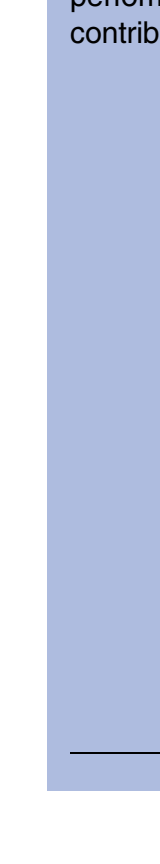

\section{construct}

Socioeconomic

status

Spatial location

System quality

Cognitive

advantage

Affective state

Interaction quality

Adaptation to

disruption

Caregiver support

Competence

Help seeking

Technological

support

Situated

decision-making
Summary results of included papers: factors that shape patient experience of long-term life-limiting conditions

Patient experience is negatively affected by inequalities related to income; ${ }^{62} 71$ age and gender; ${ }^{39} 505488$ and ethnicity ${ }^{42}$

Patients and caregiver experience is negatively affected by unequal access to services and transport, ${ }^{40} 707376$ and unequal distribution of environmental pollution ${ }^{40} 707376$

Patients and caregiver experience is negatively affected by poor professional support and material assistance, ${ }^{40} 70$ continuity of care, ${ }^{76}$ coordination of services ${ }^{43454852}$ and intraprofessional communications. ${ }^{4045474852}$ Limited professional expertise in multimorbidities, ${ }^{46}$ and slow professional responses to anxieties and emergencies ${ }^{76}$ are also markers of poor system quality

Patients and caregivers are cognitively disadvantaged by lack of educational resources ${ }^{57}$ and information. ${ }^{78} 81$ Disadvantage is exacerbated by poor understanding

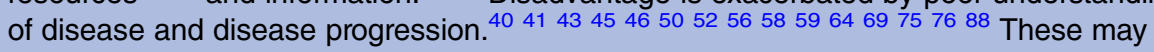
lead to hypervigilance about symptoms, poor or confused symptom recognition, ${ }^{4345576488}$ and ill-preparedness for crises ${ }^{45}$

Patients and caregivers may experience changes in self-identity, along with reduced self-esteem and self-worth, and loss of social functioning. 4143505460798489 They may experience increased fear, anxiety, isolation and discomfort, ${ }^{49} 5157607082$ and this may lead to inappropriate responses to acute episodes 424757677174

Good professional-patient relations, ${ }^{42} 4776$ and individualised timing and type of information delivery ${ }^{44} 537883$ can have a positive effect on patient and caregiver experience. Fear of death $^{43} 50668087$ negatively affects patient-professional interaction

Patient and caregiver experience is positively affected by adaptive processes; ${ }^{436163}$ the normalisation of experienced symptoms and physical limitations ${ }^{53} 7180$ and normalisation of self-management strategies. ${ }^{63}$ Patient and caregiver resilience, ${ }^{58} 617384$ capacity to manage uncertainty, ${ }^{39} 427682$ tolerance of disruption of everyday activities and competing clinical priorities ${ }^{43} 4546555887$ also positively affect patients experience competing clinical priorities
Caregiver support is defined by material assistance, ${ }^{38} 557184$ symptom management and self-management ${ }^{57} 616566$ and emotional and relational solidarity. ${ }^{47}$ It is negatively affected by perceived burdens and workload that interfere with normal life 38 39 7677818990

Patients and caregivers demonstrate competence when they are able to exert contro over disease progression, ${ }^{74}$ effectively participate in self-management, ${ }^{77}$ understand multimorbidities $^{46} 70$ and manage polypharmacy ${ }^{64}$

Patient and caregiver help seeking is governed by interactions between expectations of clinical interventions, ${ }^{76}$ isolation and help seeking. ${ }^{51646770}$ Help seeking is framed mainly through rational responses to emergency situations, ${ }^{73}$ and patients and caregivers valued the security and safety of hospital care ${ }^{67} 73$

Technological interventions as life sustaining; ${ }^{45} 73$ as mastery; ${ }^{84} 8590$ as burdens; ${ }^{58} 6579$ as intrusions; ${ }^{81} 90$ risks of treatment failure/complications ${ }^{8590}$

Patient and caregiver decision-making about help seeking and use of services was framed by the degree of awareness and uncertainty about prognosis; ${ }^{41} 44487583$

Difficulty and conflict over decisions ${ }^{45} 86$ could be ameliorated using tools and techniques to increase patient control ${ }^{77} 81-83$ 


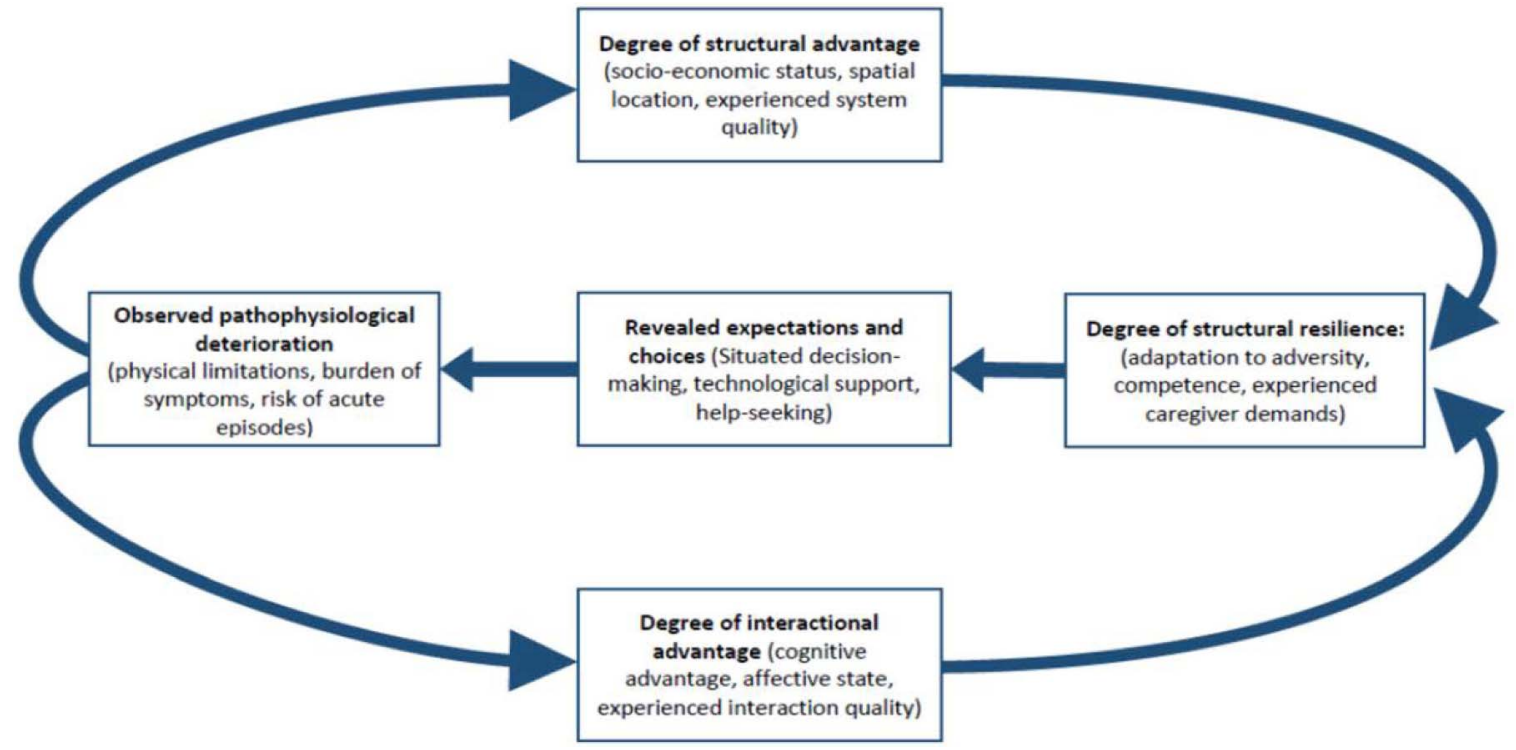

Figure 3 Factors that shape patient and caregiver expectations and choice.

about why and how patient experiences and behaviours are a problem. Using an analytic approach that focuses on identifying, characterising and explaining sets of attributions brings these factors into the foreground and helps us to detect underlying conventional assumptions. We also identified all of the underlying qualitative studies covered by these reviews. It was clear that some reviews had interrogated very similar sets of primary research papers. This may also introduce problems of publication bias.

\section{Results in context}

To the best of our knowledge, this is the first synthesis of qualitative systematic reviews focusing on patient experience of life-limiting chronic illness. Previous primary qualitative systematic reviews about the experiences of treatment burden in those with stroke and CHF excluded carer accounts and focused on developing taxonomies of treatment burden, excluding illness burden issues and did not seek to explain factors that shape patient journeys through care. ${ }^{17} 52 \quad 91$ We have explored long-term life-limiting conditions from the perspective of pathophysiological deterioration. Its point of departure was a consideration of patients' experiences of healthcare and burden of treatment in three long-term life-limiting conditions. This was situated against a background in which good decision-making about treatment, engagement with self-management and other treatment regimens, as well as conversations about end of life, are often regarded as problems of individual motivation and adherence. Many of the reviews included in this synthesis were aimed at informing professional practice and the development of interventions to support patients and caregivers with these illnesses. However, very few made concrete proposals in this regard. An analysis of this kind may be better placed to inform such work. A key finding of this synthesis is in its emphasis on what patients and caregivers value. This is not simply a matter of preferences. It also suggests that there are attributes of healthcare systems, relationships and practices that make experiences of pathophysiological deterioration worse.

\section{CONCLUSION}

An important implication of this review is that patient and caregiver expectations and choices are not random or arbitrary but are the outcome of an experiential process. A paradigm shift is called for in service development and research in this area. Interventions that seek to empower individual patients may have limited effectiveness for those who are most affected by the combined weight of structural, interactional and resilience factors identified in this synthesis. There are likely causal interactions between these different factors that need to be better characterised and understood, but linking service and intervention development with robust theoretical models and rigorous practically oriented research ought to be the strategic direction for this. As a start in this direction, we have proposed domains of patient and caregiver experience that may represent good targets for new interventions that respond to the combined disadvantages that they may face.

\section{Author affiliations}

${ }^{1}$ Faculty of Health Sciences, University of Southampton, Southampton, UK

${ }^{2}$ NIHR CLAHRC Wessex, University of Southampton, Southampton, UK ${ }^{3}$ University Hospital Southampton NHS Foundation Trust, Southampton, UK ${ }^{4}$ Faculty of Medicine, University of Southampton, Southampton General Hospital, Southampton, UK

${ }^{5}$ York Health Economics Consortium, University of York, York, UK

${ }^{6}$ Knowledge and Evaluation Research Unit, Mayo Clinic, Rochester, Minnesota, USA

${ }^{7}$ Department of General Practice and Primary Care, Institute of Health and Wellbeing, University of Glasgow, Glasgow, UK 
Twitter Follow Carl May at @CarlRMay and Frances Mair at @FrancesMair

Acknowledgements The authors thank Dr Susi Lund for acting as impartial arbiter in cases of disagreement about inclusion in this review; Dr Michael Bracher for his help with setting up the screening databases; Margaret Bush, Trisha Durrant and Zena Galbraith for their assistance with data preparation; and Christine May for her helpful and perceptive comments on the manuscript.

Contributors CRM drafted this paper; CRM, AR, KB and FSM developed the conceptual framework informing this study; CRM, PG, MM, CP, PR and AR designed the review; MA performed database searches; AC, MM and CRM screened titles, abstracts and full papers with assistance from JH; CRM performed first-line content analysis; MA, KB, AC, PG, JH, FSM, MM, CP, AR and PR critically reviewed the manuscript for important intellectual content; all authors approved the final version of the paper. CRM is guarantor.

Funding This work was supported by the National Institute for Health Research Collaboration for Leadership in Applied Health Research and Care (NIHR CLAHRC) Wessex which is a partnership between Wessex NHS organisations and partners and the University of Southampton. Funders had no role in study design, data collection and analysis, decision to publish or preparation of the manuscript.

Disclaimer The views expressed are those of the author(s) and not necessarily those of the NHS, the NIHR or the Department of Health.

Competing interests CP declares consultancy payments from National Institute for Health and Care Excellence and the Department of Health.

Provenance and peer review Not commissioned; externally peer reviewed.

Data sharing statement No additional data are available.

Open Access This is an Open Access article distributed in accordance with the terms of the Creative Commons Attribution (CC BY 4.0) license, which permits others to distribute, remix, adapt and build upon this work, for commercial use, provided the original work is properly cited. See: http:// creativecommons.org/licenses/by/4.0/

\section{REFERENCES}

1. Garin N, Koyanagi A, Chatterji S, et al. Global Multimorbidity Patterns: A Cross-Sectional, Population-Based, Multi-Country Study. J Gerontol A Biol Sci Med Sci. 2015:glv128.

2. May C, Eton DT, Boehmer KR, et al. Rethinking the patient: using Burden of Treatment Theory to understand the changing dynamics of illness. BMC Health Serv Res. 2014;14:281.

3. Holman HR. Chronic illness and the healthcare crisis. Chronic IIIn 2006;1:265-74

4. May C. Chronic illness and intractability: professional-patient interactions in primary care. Chronic IIIn 2005;1:15-20.

5. Bury M. Chronic illness as biographical disruption. Sociol Health IIIn 1982:4:167-82.

6. Lawton J. Lay experiences of health, illness: past research, future agendas. Sociol Health IIIn 2003;25:23-40.

7. Chapple A, Rogers A. 'Self-care' and its relevance to developing demand management strategies: a review of qualitative research. Health Soc Care Community 1999;7:445-54.

8. Gately C, Rogers A, Kirk S, et al. Integration of devices into long-term condition management: a synthesis of qualitative studies. Chronic IIIn 2008;4:135-48.

9. Gately C, Rogers A, Sanders C. Re-thinking the relationship between long-term condition self-management education and the utilisation of health services. Soc Sci Med 2007;65:934-45.

10. Lewis KB, Stacey D, Matlock DD. Making Decisions About Implantable Cardioverter-Defibrillators from Implantation to End of Life: An Integrative Review of Patients' Perspectives. Patient-Patient Centered Outcomes Research 2014;7:243-60.

11. May C, Montori VM, Mair FS. We need minimally disruptive medicine. BMJ. 2009;339:b2803

12. Shippee ND, Shah ND, May CR, et al. Cumulative complexity: a functional, patient-centered model of patient complexity can improve research and practice. J Clin Epidemiol 2012;65:1041-51.

13. Zullig LL, Whitson HE, Hastings SN, et al. A Systematic Review of Conceptual Frameworks of Medical Complexity and New Model Development. J Gen Intern Med 2015:1-9.
14. Boger E, Ellis J, Latter S, et al. Self-management and self-management support outcomes: A systematic review and mixed research synthesis of stakeholder views. PloS ONE 2015;10: e0130990.

15. Demain S, Gonçalves A-C, Areia C, et al. Living With, Managing and Minimising Treatment Burden in Long Term Conditions: A Systematic Review of Qualitative Research. PloS ONE 2015;10: e0125457

16. Eton DT, de Oliveira DR, Egginton JS, et al. Building a measurement framework of burden of treatment in complex patients with chronic conditions: a qualitative study. Patient Relat Outcome Meas 2012;3:39.

17. Eton DT, Elraiyah TA, Yost KJ, et al. A systematic review of patient-reported measures of burden of treatment in three chronic diseases. Patient Relat Outcome Meas 2013;4:7-20.

18. Eton DT, Ridgeway JL, Egginton JS, et al. Finalizing a measurement framework for the burden of treatment in complex patients with chronic conditions. Patient Relat Outcome Meas 2015;6:117.

19. Sav A, Kendall E, McMillan SS, et al. 'You say treatment, I say hard work': treatment burden among people with chronic illness and their carers in Australia. Health Soc Care Community 2013;21:665-74.

20. Sav A, King MA, Whitty JA, et al. Burden of treatment for chronic illness: a concept analysis and review of the literature. Health Expect 2013.

21. Islam R, Weir C, Del Fiol G. Clinical Complexity in Medicine: A Measurement Model of Task and Patient Complexity. Methods Inf Med 2016;55:14-22.

22. Grembowski D, Schaefer J, Johnson KE, et al. A Conceptual Model of the Role of Complexity in the Care of Patients With Multiple Chronic Conditions. Med Care 2014:52:S7-S14.

23. Bohlen K, Scoville E, Shippee ND, et al. Overwhelmed Patients A videographic analysis of how patients with type 2 diabetes and clinicians articulate and address treatment burden during clinical encounters. Diabetes Care 2012;35:47-9.

24. May $C$. Mundane medicine, therapeutic relationships, and the clinical encounter. In: Pescosolido B, Martin JA, Rogers A, eds. Handbook of the sociology of health, illness, and healing: a blueprint for the 21st century New York: Springer, 2010:309-22.

25. Vassilev I, Rogers A, Kennedy A, et al. The influence of social networks on self-management support: a metasynthesis. Public Health 2014;14:719.

26. Pearce N, Davey Smith G. Is social capital the key to inequalities in health? American journal of public health. 2003;93:122-9.

27. Murray SA, Kendall M, Boyd K, et al. Illness trajectories and palliative care. In Sallnow L, Kumar S, Kellehear A, eds. Int Perspect Public Health Palliat Care 2012:30;2017-19.

28. May CR, Masters J, Welch L, et al. EXPERTS 1-experiences of long-term life-limiting conditions among patients and carers: protocol for a qualitative meta-synthesis and conceptual modelling study. BMJ Open 2015;5:e007372.

29. Tong $A$, Sainsbury $P$, Craig J. Consolidated criteria for reporting qualitative research (COREQ): a 32-item checklist for interviews and focus groups. Int J Qual Health Care 2007;19:349-57.

30. Tong A, Flemming K, Mclnnes $\mathrm{E}$, et al. Enhancing transparency in reporting the synthesis of qualitative research: ENTREQ. BMC Med Res Methodol 2012;12:181.

31. Clark J. How to peer review a qualitative manuscript. In: Godlee F Jefferson T, eds. Peer Review in Health Sciences 2nd ed. London: BMJ Books; 2003;219-35.

32. Shea BJ, Grimshaw JM, Wells GA, et al. Development of AMSTAR: a measurement tool to assess the methodological quality of systematic reviews. BMC Med Res Methodol 2007;7:1-7.

33. Campbell R, Pound P, Morgan M, et al. Evaluating meta ethnography: systematic analysis and synthesis of qualitative research. Health Technol Assess 2012.

34. Mays $\mathrm{N}$, Pope $\mathrm{C}$. Assessing quality in qualitative research. BMJ 2000;320:50.

35. Hsieh $\mathrm{H}-\mathrm{F}$, Shannon SE. Three approaches to qualitative content analysis. Qual Health Res 2005;15:1277-88.

36. Banister P, Burman E, Parker I, et al. Qualitative methods in psychology: a research guide Buckingham: Open University Press; 1994

37. Kelley $\mathrm{HH}$, Michela JL. Attribution theory and research. Annu Rev Psychol 1980;31:457-501.

38. Molloy GJ, Johnston DW, Witham MD. Family caregiving and congestive heart failure. Review and analysis. Eur J Heart Fail 2005;7:592-603.

39. Yu DS, Lee DT, Kwong AN, et al. Living with chronic heart failure: a review of qualitative studies of older people. J Adv Nurs 2008;61:474-83.

40. McEntee ML, Cuomo LR, Dennison CR. Patient-, provider-, and system-level barriers to heart failure care. J Cardiovasc Nurs 2009;24:290-8. 
41. Welstand J, Carson A, Rutherford P. Living with heart failure: An integrative review. Int J Nurs Stud 2009;46:1374-85.

42. Hopp FP, Thornton N, Martin L. The lived experience of heart failure at the end of life: a systematic literature review. Health Soc Work 2010;35:109-17.

43. Jeon $\mathrm{YH}, \mathrm{Kraus} \mathrm{SG}$, Jowsey $\mathrm{T}$, et al. The experience of living with chronic heart failure: a narrative review of qualitative studies. BMC Health Serv Res 2010;10:77.

44. Barclay S, Momen N, Case-Upton S, et al. End-of-life care conversations with heart failure patients: a systematic literature review and narrative synthesis. Br J Gen Pract. 2011;61:e49-62.

45. Dev S, Abernethy AP, Rogers JG, et al. Preferences of people with advanced heart failure-a structured narrative literature review to inform decision making in the palliative care setting. Am Heart $J$ 2012;164:313-9.e5.

46. Dickson VV, Buck H, Riegel B. A qualitative meta-analysis of heart failure self-care practices among individuals with multiple comorbid conditions. J Card Fail 2011;17:413-9.

47. Kang X, Li Z, Nolan MT. Informal caregivers' experiences of caring for patients with chronic heart failure: systematic review and metasynthesis of qualitative studies. J Cardiovasc Nurs 2011;26:386-94.

48. Low J, Pattenden J, Candy B, et al. Palliative care in advanced heart failure: an international review of the perspectives of recipients and health professionals on care provision. $J$ Card Fail 2011;17:231-52.

49. Tierney S, Mamas M, Skelton D, et al. What can we learn from patients with heart failure about exercise adherence? A systematic review of qualitative papers. Health Psychol 2011;30:401-10.

50. Thomas JR, Clark AM. Women with heart failure are at high psychosocial risk: A systematic review of how sex and gender influence heart failure self-care. Cardiol Res Pract 2011;1.

51. Clark AM, Savard LA, Spaling MA, et al. Understanding help-seeking decisions in people with heart failure: a qualitative systematic review. Int J Nurs Stud 2012;49:1582-97.

52. Jani B, Blane D, Browne $S$, et al. Identifying treatment burden as an important concept for end of life care in those with advanced heart failure. Curr Opin Support Palliat Care 2013;7:3-7.

53. Procter E. Collaboration between the specialties in provision of end-of-life care for all in the UK: reality or utopia? int $J$ Palliat Nurs 2012;18:339-47.

54. Rolls TP, Young LE. Disrupting the Biomedical Discourse: Older Women's Lived Experiences with Heart Failure: A Feminist Review of the Literature. Can J Cardiovasc Nurs 2012;22:18-25.

55. Buck HG, Harkness K, Wion R, et al. Caregivers' contributions to heart failure self-care: A systematic review. Eur $\mathrm{J}$ Cardiovasc Nurs 2015;14:79-89.

56. Falk H, Ekman I, Anderson R, et al. Older patients' experiences of heart failure-an integrative literature review. J Nurs Scholarsh 2013:45:247-55.

57. Siabani S, Leeder SR, Davidson PM. Barriers and facilitators to self-care in chronic heart failure: a meta-synthesis of qualitative studies. SpringerPlus 2013;2:320.

58. Sookhoo D, Pellowe C, Derham C. The experiences of heart failure patients following their participation in self-management patient education programmes: A systematic review. JBI Database System Rev Implement Rep 2013;11:236-80.

59. Clark AM, Spaling M, Harkness K, et al. Determinants of effective heart failure self-care: a systematic review of patients' and caregivers' perceptions. Heart 2014;100:716-21.

60. Dekker RL. Patient perspectives about depressive symptoms in heart failure: a review of the qualitative literature. $J$ Cardiovasc Nurs 2014;29:E9-15

61. Harkness K, Spaling MA, Currie K, et al. A systematic review of patient heart failure self-care strategies. $J$ Cardiovasc Nurs 2015;30:121-35

62. Strachan $\mathrm{PH}$, Currie $\mathrm{K}$, Harkness $\mathrm{K}$, et al. Context matters in heart failure self-care: a qualitative systematic review. $J$ Card Fail 2014:20:448-55.

63. Wingham J, Harding G, Britten N, et al. Heart failure patients attitudes, beliefs, expectations and experiences of self-management strategies: a qualitative synthesis. Chronic IIIn 2014;10:135-54.

64. Gysels M, Bausewein C, Higginson IJ. Experiences of breathlessness: a systematic review of the qualitative literature. Palliat Support Care 2007:5:281-302.

65. Cullen DL, Stiffler D. Long-term oxygen therapy: Review from the patientsg perspective. Chron Respir Dis 2009;6:141-7.

66. Disler RT, Gallagher RD, Davidson PM. Factors influencing self-management in chronic obstructive pulmonary disease: an integrative review. Int J Nurs Stud 2012;49:230-42.
67. Keating A, Lee A, Holland AE. What prevents people with chronic obstructive pulmonary disease from attending pulmonary rehabilitation? A systematic review. Chron Respir Dis 2011;8:89-99.

68. Kirkpatrick P, Wilson E, Wimpenny P. Support for older people with COPD in community settings: A systematic review of qualitative research. JBI Database System Rev Implement Rep 2012:10:3649-763.

69. Giacomini M, DeJean D, Simeonov D, et al. Experiences of living and dying with COPD: a systematic review and synthesis of the qualitative empirical literature. Ont Health Technol Assess Ser 2012;12:1-47.

70. Thorpe O, Johnston K, Kumar S. Barriers and enablers to physical activity participation in patients with COPD: a systematic review. Journal of Cardiopulmonary Rehabilitation \& Prevention 2012;32:359-69.

71. Langer S, Chew-Graham C, Hunter C, et al.. Why do patients with long-term conditions use unscheduled care? A qualitative literature review. Health Soc Care Community 2013;21:339-51.

72. Momen N, Hadfield P, Kuhn I, et al. Discussing an uncertain future: end-of-life care conversations in chronic obstructive pulmonary disease. A systematic literature review and narrative synthesis. Thorax 2012;67:777-80.

73. de Sousa Pinto JM, Martin-Nogueras AM, Morano MT, et al. Chronic obstructive pulmonary disease patients' experience with pulmonary rehabilitation: a systematic review of qualitative research. Chron Respir Dis 2013;10:141-57.

74. Harrison SL, Apps L, Singh SJ, Steiner MC, et al. 'Consumed by breathing' - a critical interpretive meta-synthesis of the qualitative literature. Chronic IIIn 2014;10:31-49.

75. Disler RT, Green A, Luckett T, et al. Experience of advanced chronic obstructive pulmonary disease: metasynthesis of qualitative research. J Pain Symptom Manage 2014;48:1182-99.

76. Oishi A, Murtagh FE. The challenges of uncertainty and interprofessional collaboration in palliative care for non-cancer patients in the community: a systematic review of views from patients, carers and health-care professionals. Palliat Med 2014;28:1081-98.

77. Low J, Smith G, Burns A, et al. The impact of end-stage kidney disease (ESKD) on close persons: A literature review. NDT Plus 2008;1:67-79.

78. Morton RL, Tong A, Howard K, et al. The views of patients and carers in treatment decision making for chronic kidney disease: systematic review and thematic synthesis of qualitative studies. BMJ 2010;340:c112.

79. Wadd K, King L, Bennett P, et al. Being a parent on dialysis: a literature review. J Ren Care 2011;37:208-15.

80. Bayhakki, Hatthakit U. Lived experiences of patients on hemodialysis: a meta-synthesis. Nephrol Nurs J 2012;39:295-304;quiz 5.

81. Harwood L, Clark AM. Understanding pre-dialysis modality decision-making: A meta-synthesis of qualitative studies. Int $J$ Nurs Stud 2013;50:109-20.

82. Makaroff KL. Experiences of kidney failure: a qualitative meta-synthesis. Nephrol Nurs J 2012;39:21-9, 80; quiz 30.

83. Moustakas J, Bennett PN, Nicholson J, et al. The needs of older people with advanced chronic kidney disease choosing supportive care: a review. Ren Soc Aust J 2012;8:70-5.

84. Tong A, Lesmana B, Johnson DW, et al. The perspectives of adults living with peritoneal dialysis: thematic synthesis of qualitative studies. Am J Kidney Dis 2013;61:873-88.

85. Casey JR, Hanson CS, Winkelmayer WC, et al. Patients' perspectives on hemodialysis vascular access: a systematic review of qualitative studies. Am J Kidney Dis 2014;64:937-53.

86. Luckett T, Sellars M, Tieman J, et al. Advance care planning for adults with CKD: a systematic integrative review. Am J Kidney Dis 2014;63:761-70.

87. Palmer SC, Hanson CS, Craig JC, et al. Dietary and Fluid Restrictions in CKD: A Thematic Synthesis of Patient Views From Qualitative Studies. Am J Kidney Dis 2015;65:559-73.

88. Tong A, Jesudason S, Craig JC, et al. Perspectives on pregnancy in women with chronic kidney disease: systematic review of qualitative studies. Nephrol Dial Transplant 2015;30:652-61.

89. Tong A, Cheung KL, Nair SS, et al. Thematic synthesis of qualitative studies on patient and caregiver perspectives on end-of-life care in CKD. Am J Kidney Dis 2014;63:913-27.

90. Walker RC, Hanson CS, Palmer SC, et al. Patient and caregiver perspectives on home hemodialysis: a systematic review. Am J Kidney Dis 2015:65:451-63.

91. Gallacher K, Morrison D, Jani B, et al. Uncovering treatment burden as a key concept for stroke care: a systematic review of qualitative research. PLoS Med 2013;10:e1001473. 